\title{
Influence of irrigation strategies on productivity, fruit quality and soil-plant water status of subsurface drip-irrigated apple trees
}

\author{
Azzeddine Chenafi ${ }^{1,4}$, Philippe Monney ${ }^{2 \star}$, Eva Arrigoni ${ }^{3}$, Abderrahmane Boudoukha ${ }^{4}$ \\ and Christoph Carlen ${ }^{2}$ \\ 1 Department of Hydraulics, University of Bejaia, Algeria \\ 2 Agroscope, Institute for Plant Production Sciences, 1964 Conthey, Switzerland \\ 3 Agroscope, Institute for Food Sciences, 8820 Wädenswil, Switzerland \\ 4 Department of Hydraulics, University of Batna, Algeria
}

Received 8 July 2014 - Accepted 2 October 2015

\begin{abstract}
Introduction. The aim of this work was to study the effects of regulated deficit irrigation (RDI) on fruit yield, fruit weight and fruit quality parameters, as well as soil-plant water relations, in apple orchards under highfrequency subsurface drip irrigation in a region with a continental climate. Materials and methods. Four irrigation treatments were applied in 2010 and 2011 to apple trees cv. 'Gala': T1, no irrigation; T2, optimal irrigation except during summer; T3, optimal irrigation except during summer when RDI with a threshold for irrigation at $-1.2 \mathrm{MPa}$ midday stem water potential ( $\Psi$ stem) was utilised; T4, optimal irrigation. The soil water status and plant water status were followed over two growing seasons. Results and discussion. The irrigation treatments had no significant impact on fruit yield. However, compared with optimal irrigation (T4) and RDI (T3), the absence of irrigation in summer (T1, T2) induced low $\Psi$ stem $(<-1.2 \mathrm{MPa})$, decreased fruit size and slightly increased the soluble solid, vitamin $\mathrm{C}$ and polyphenol contents of the fruits. The RDI (T3) during summer allowed a water-use reduction of $47 \%$ without loss in fruit yield, fruit weight and fruit quality compared with the optimal irrigation (T4). Conclusion. The RDI treatment saved $47 \%$ water compared with optimal irrigation without negative impacts on yield and fruit quality. In the temperate conditions of Switzerland, $\Psi$ stem, as well as $\Psi$ soil, are well adapted for scheduling RDI in apple orchards.
\end{abstract}

Keywords: Switzerland / apple / Malus domestica / irrigation scheduling / regulated deficit irrigation / water stress / phenolics / vitamin C

Résumé - Influence de stratégies d'irrigation sur la productivité, la qualité des fruits et le statut hydrique sol-plante de pommiers arrosés en goutte à goutte enterré. Introduction. Le but de cette étude a été d'analyser les effets de la régulation déficitaire de l'irrigation (RDI), avec des applications d'eau en goutte à goutte enterré à fréquence élevée, sur le rendement en fruits, le poids des fruits, et la qualité des fruits, ainsi que sur les relations hydriques entre sol et plante sur des vergers de pommier sous un climat continental. Matériel et méthodes. Quatre procédés d'irrigation ont été appliqués aux pommiers (cv. 'Gala') en 2010 et 2011 : T1, témoin non irrigué; T2, irrigation optimal à l'exception d'absence d'irrigation durant l'été; T3, irrigation optimal à l'exception une restriction d'irrigation induisant un stress modéré durant l'été, avec un seuil fixé à -1.2 MPa de $\Psi$ stem (irrigation déficitaire régulée, RDI); T4, irrigation optimale. L'impact de ces régimes sur le potentiel hydrique du sol ( $\Psi$ soil) et le potentiel hydrique du tronc ( $\Psi$ stem) a été suivi pendant deux saisons. Résultats et discussion. Les régimes d'irrigation n'ont eu aucun impact significatif sur le rendement en fruits. Toutefois, par rapport à l'irrigation optimale (T4) et RDI (T3), l'absence d'irrigation en été (T1, T2) induit des potentiels de tronc bas ( $\Psi_{\text {stem }}<-1,2 \mathrm{MPa}$ ) et une diminution du poids des fruits. Par contre, les teneurs en sucre, en vitamine $\mathrm{C}$ et en polyphénols des fruits sont tendanciellement augmentées. Le procédé RDI (T3) au cours de l'été, a permis une réduction de la consommation d'eau de $47 \%$ sans perte de rendement en fruits, de poids et de la qualité des fruits par rapport à l'irrigation optimale (T4). Conclusion. Le procédé RDI (T3) a économisé $47 \%$ d'eau par rapport à l'irrigation optimale (T4), sans effets négatifs sur le rendement et la qualité des fruits. Dans les conditions environnementales de la Suisse, le potentiel hydrique du tronc ( $\Psi$ stem)

^ Corresponding author: philippe.monney@agroscope.admin.ch 
ainsi que le potentiel hydrique du sol ( $\left.\Psi_{\text {soil }}\right)$ sont bien adaptés pour gérer l'irrigation déficitaire dans des vergers de pommiers.

Mots clés : Suisse / pomme / Malus domestica / gestion de l'irrigation / irrigation déficitaire régulée (RDI) / stress hydrique / composés phénoliques / vitamine C

\section{Introduction}

Considering the increasing world population and climate change, water can become a limiting factor for agriculture [1]. In this context, increasing water-use efficiency is a vital issue for socio-economic development in many regions. More efficient water use is possible with improvements in plant breeding to enable crops to grow successfully in drought environments and in irrigation management, as well as in irrigation systems such as subsurface drip irrigation $[1,2]$. This system delivers water directly to the root zone and minimises soil surface evaporation, runoff and deep percolation [2-5]. Another promising approach, especially for fruit crops, is regulated deficit irrigation (RDI), which aims to reduce irrigation during specific phenological stages without risk of loss to yield and fruit quality [6-13]. The concept of RDI was first proposed to control vegetative growth in peach orchards without influencing fruit yield $[14,15]$. Studies on peach and apricot revealed that yield, fruit size and fruit quality can be maintained under conditions of mild to moderate plant stress when applied during some phenological stages [6-8]. RDI was also successfully applied to apple [9-13], citrus [16], almond [17] and loquat [18].

Moderate water stress with RDI can influence fruit quality parameters. Studies on peaches and apples showed that moderate water stress induced higher fruit sugar contents [19,20]. The contribution of apple products, possessing a wide range of biological activities with beneficial protective effects for health against cardiovascular disease, asthma and pulmonary dysfunction, diabetes, obesity, and cancer, has been reviewed [21] and confirmed by epidemiological observations, indicating that regular consumption of one or more apples per day may reduce the risk of certain cancers [22]. However, there is little information on the effects of different irrigation treatments on the nutritional parameters of apple fruit.

To manage irrigation, different methods have been used to monitor soil humidity and identify the actual plant water status, including tensiometers [23], granular matrix sensors [24] and capacitance probes [25]. Soil water status has long been used for scheduling irrigation [26], and is one of the most useful scheduling methods available, due to its practicability and low cost [27]. Using soil-based measurements for RDI presupposes the existence of a reliable plant-based indicator and a threshold that can be used to predict the absence of impact on yield and fruit quality. The relationship of the midday stem water potential $(\Psi$ stem $)$ and fruit size has been analysed for apple by Naor [28]. It appears that the proportion of fruits larger than $65 \mathrm{~mm}$ measured at harvest significantly decreases with -1.2 to $-1.3 \mathrm{MPa} \Psi$ stem. This was confirmed in a Spanish trial, in which none of the deficit treatments ranging from -1.1 to $-1.2 \mathrm{MPa}$ throughout the season differed from the control in yield and fruit size at harvest, while those reaching values
Table I. Soil characteristics of the experimental site at four different depths measured at the beginning of the experiment in 2010.

\begin{tabular}{lccccc}
\hline Soil & Organic & & \multicolumn{3}{c}{ Soil granulometry } \\
\cline { 4 - 6 } $\begin{array}{l}\text { Depth } \\
(\mathrm{m})\end{array}$ & $\begin{array}{c}\text { matter } \\
(\%)\end{array}$ & $\mathrm{pH}$ & $\begin{array}{c}\text { Clay } \\
(\%)\end{array}$ & $\begin{array}{c}\text { Silt } \\
(\%)\end{array}$ & $\begin{array}{c}\text { Sand } \\
(\%)\end{array}$ \\
\hline $0.00-0.25$ & 3.7 & 8.0 & 24.2 & 40.4 & 35.3 \\
$0.25-0.50$ & 3.3 & 8.1 & 23.5 & 41.6 & 35.0 \\
$0.50-0.75$ & 2.0 & 8.2 & 22.4 & 43.5 & 34.1 \\
$0.75-0.10$ & 2.4 & 8.2 & 23.9 & 43.2 & 32.9 \\
\hline
\end{tabular}

lower than -1.4 MPa from mid-July showed a significant decrease in both parameters [29]. $\Psi_{\text {stem }}$ has been successfully used in dominant anisohydric species or cultivars such as fruit trees [30], prune [31,32], apple [33], almond [34] and citrus trees [35], as well as vineyards [36]. However, it has been shown that for species or cultivars with dominant isohydric behaviour, this indicator is replaced by leaf water potential measured at predawn $(\Psi p d)$ [37].

This study specifically addresses subsurface drip irrigation and will evaluate the impact of different irrigation strategies no irrigation, RDI and comfort irrigation - on fruit yield, fruit weight and fruit quality, including vitamin $\mathrm{C}$, total polyphenol content (TPC) and antioxidative potential. Furthermore, information is scant about soil and plant water status with highfrequency subsurface drip irrigation. The relationship between the plant and soil water status at different soil depths was assessed in order to define accurate measurement methods with their corresponding threshold values for scheduling RDI in orchards.

\section{Materials and methods}

\subsection{Experimental site, plant material}

The experiment was conducted in an experimental orchard located at Agroscope in Conthey, Switzerland (latitude $46^{\circ} 12^{\prime} \mathrm{N}$, longitude $7^{\circ} 18^{\prime} \mathrm{E}$, altitude $500 \mathrm{~m}$ ). The climate is continental, with high daily and seasonal variations in temperature. The average temperature from 1978 to 2007 was $9.9^{\circ} \mathrm{C}$, the average annual rainfall was $630 \mathrm{~mm}$ and the calculated water deficit during the vegetation period for apple trees was $275 \mathrm{~mm}$.

Soil analyses were carried out from 15 samples randomly taken in March 2010 at four different depths (table I). According to the American Unified Soil Classification System (USCS) standard, the soil is a loam, with $\mathrm{pH}$ ranging from 8.0 (soil) to 8.2 (subsoil) and organic matter decreasing from $3.7 \%$ at $25 \mathrm{~cm}$ depth to $2.4 \%$ at $100 \mathrm{~cm}$ depth. Gravel does not exceed $10 \%$. Soil fertility is at an optimal level for phosphorus and above the optimum for potassium and magnesium. 


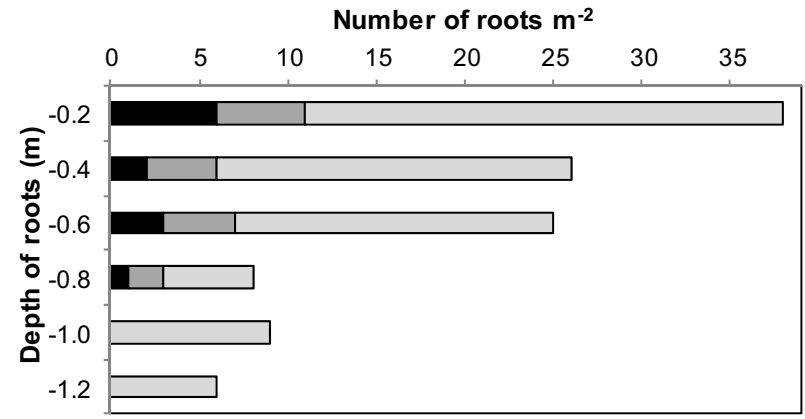

Figure 1. Distribution of roots of Gala apple trees grafted on M9 at the beginning of the experiment in 2010 in different soil layers of $0.20 \mathrm{~m}$ according to their diameters: thick roots $(>5 \mathrm{~mm})$, medium roots $(>1$ to $<5 \mathrm{~mm})$, fine roots $(<1 \mathrm{~mm})$, observed on a soil profile $1.2 \mathrm{~m}$ deep and $3.0 \mathrm{~m}$ wide.

The experimental orchard was planted in 2002 with cv. Royal Gala ${ }^{\circledR}$ on M9 rootstock, clone FL 56. Trees are trained in two different systems: a three-axis V-shape system, $2.8 \mathrm{~m}$ high, and a vertical two-axis hedge system, $3.5 \mathrm{~m}$ high. Planting density was $4.0 \mathrm{~m} \times 1.4 \mathrm{~m}\left(1,800\right.$ trees $\left.^{-1}\right)$ for both systems, and the rows are north-south oriented. The orchard was fertilised with $60 \mathrm{~kg} \mathrm{~N}, 10 \mathrm{~kg} \mathrm{P}$ and $40 \mathrm{~kg} \mathrm{~K}$ according to guidelines for integrated production [38]. The full bloom of Gala was on April 26th in 2010 and April 18th in 2011, and fruits were harvested on August $24^{\text {th }}$ in 2010 and August 19 ${ }^{\text {th }}$ in 2011. The root distribution of the Gala apple trees is shown in figure 1 , indicating that most roots were found between 20 and $60 \mathrm{~cm}$ depth. Some fine roots were found down to $1.2 \mathrm{~m}$.

Subsurface drip irrigation was carried out with two dripper lines (CNL Uniram, $30 \mathrm{~cm}, 1.6 \mathrm{~L} \mathrm{~h}^{-1}$, Netafim Ltd., Tel Aviv, Israel) installed $0.5 \mathrm{~m}$ from the tree row and at a soil depth of $0.25 \mathrm{~m}$. The dripper flow rate of $1.6 \mathrm{~L} \mathrm{~h}^{-1}$ and dripper spacing of $0.3 \mathrm{~m}$ was chosen for homogeneous water distribution achieved with a pressure compensating system (1.0-4.0 bar). Irrigation was automatically set to $2-4$ pulses day ${ }^{-1}$ with duration of 3 to 12 min per pulse depending on the season and the total water volume to be distributed every day. Adjustments were made once a week to keep soil humidity as constant as possible at $-0.03 \mathrm{MPa}$ for the treatments and periods when optimal irrigation had to be applied.

\subsection{Irrigation treatments and experimental design}

The soil of the experimental orchard was completely covered by a transparent plastic foil to avoid penetration of the rainwater to the roots. Furthermore, the plastic foil was covered by green plastic to limit the influence of solar radiation on the soil temperature. The slight inclination of the field by $1-2 \%$ allowed rainwater to flow superficially out of the orchard.

The irrigation treatment experiments were based on three fruit-growing periods according to the recommendation of the Food and Agriculture Organization (FAO) [39]: P1, from full bloom to the end of fruit cell division (about 60 days for apples); P2, corresponding to the fruit cell growing period (from the beginning of July to the beginning of August); and P3, about 3 to 4 weeks before harvest.
The following four irrigation treatments were applied: $\mathrm{T} 1$, no irrigation from full bloom to harvest (P1 to P3); T2, optimal irrigation during $\mathrm{P} 1$ and $\mathrm{P} 3$, no irrigation during $\mathrm{P} 2$; T3, optimal irrigation during P1 and P3, application of deficit irrigation (as a way to maintain $\Psi$ stem at about -1.2 MPa during P2; this threshold is supposed to ensure sufficient water supply to the plants and avoid negative impacts on the yield and quality of fruit [40]); and T4, optimal irrigation from full bloom to harvest. The trees were irrigated according to soil water potential ( $\Psi$ soil $)$ at the threshold value of $-0.03 \mathrm{MPa}$ (measured with sensors at a soil depth of $0.3 \mathrm{~m}$ ), except the T3 treatment with RDI during P2.

The experimental design is a split plot with three replications and four irrigation treatments. Each plot contained 18 trees, with two subplots of 9 trees per tree shape (the threeaxis V-shape system and vertical two-axis system). Plant water status and fruit yield and quality were measured separately on two individuals per subplot. However, the results of both shapes were pooled, because there were no significant interactions between irrigation treatments and tree shapes for the parameters analysed.

\subsection{Yield, fruit weight and stem development}

The fruits from each of the two reference trees of every subplot were individually harvested at the end of August in 2010 and 2011. Total yield (in $\mathrm{kg}$ ) and number of fruits, as well as the individual fruit weight and colour, were obtained with a sorting machine (Greefa, Tricht, The Netherlands), dividing Class A fruits (fruit diameter of 65 to $80 \mathrm{~mm}$ ) from the other fruits. The trunk circumference was measured at $0.2 \mathrm{~m}$ above the grafting point at the end of the vegetation period in autumn.

\subsection{Fruit quality parameters}

Tests for soluble solid contents (SSC, ${ }^{\circ}$ Brix), acidity (malic acid, $\left.\mathrm{g} \mathrm{L}^{-1}\right)$ and firmness $\left(\mathrm{kg} \mathrm{cm}^{-2}\right)$ were performed on a random sample of 20 fruits per tree at harvest using the semi-automatic Pimprenelle robotic machine (Setop Giraud Technology, France) [41]. This instrument consists of three measuring units: a penetrometer, optical refractometer and titrator.

Sampling and sample treatment for the quantification of the total phenolic content (TPC) and antioxidative potential by ferric reducing antioxidant power (FRAP) were done as described in other studies [42, 43]. At harvest, 20 fruits out of the whole production per tree were randomly chosen and pooled in one sample. The 20 fruits were sliced with an apple divider (Divisorex, Famos-Westmark GmbH, LennestadtElspe, Germany) into 10 pieces plus the core area. The core area was discarded. Two opposite slices of each fruit were randomly chosen and immediately frozen in liquid nitrogen, and all 40 frozen slices were pooled as a representative sample. The frozen apple pieces were crushed in a dry ice mill (Meidinger AG, Kaiseraugst, Switzerland) and ground to fine powder with a cutter (La Moulinette DPA 1, Moulinex, Germany). Afterwards, the samples were stored at $-20{ }^{\circ} \mathrm{C}$ until extraction. Extraction was carried out by mixing $2.5 \mathrm{~g}$ frozen powder with $50 \mathrm{~mL}$ methanol containing $1 \%$ formic acid (v/v) and 
Table II. Water applied, fruit yield, class A fruits, fruit weight and trunk diameter in 2010 and 2011 in relation to the different irrigation strategies: no irrigation (T1); optimal irrigation except no irrigation during July to the beginning of August (T2); optimal irrigation except regulated deficit irrigation (RDI) during July to the beginning of August (T3); optimal irrigation (T4). Each value of the agronomic parameters corresponds to the mean ( \pm standard deviation) of 2 training systems and 3 replications. Different letters indicate significant differences among the treatments (Tukey, $P<0.05$ ).

\begin{tabular}{|c|c|c|c|c|c|c|}
\hline \multirow[b]{2}{*}{ Years } & \multirow{2}{*}{\multicolumn{2}{|c|}{$\begin{array}{c}\text { Treatments } \\
\text { Water applied } \\
\left(\mathrm{L} \mathrm{m}^{-2}\right)\end{array}$}} & \multicolumn{4}{|c|}{ Agronomic parameters } \\
\hline & & & $\begin{array}{l}\text { Total yield } \\
\left(\mathrm{kg} \mathrm{tree}^{-1}\right)\end{array}$ & $\begin{array}{c}\text { Class A } \\
\text { fruits }(\%)\end{array}$ & $\begin{array}{l}\text { Fruit weight } \\
(\mathrm{g})\end{array}$ & $\begin{array}{l}\text { Trunk diameter } \\
(\mathrm{mm})\end{array}$ \\
\hline \multirow[t]{4}{*}{2010} & $\mathrm{~T} 1$ & 0 & $19.5 \pm 7.0$ & $58 \pm 14$ & $121 \pm 16 b$ & $54.0 \pm 4.4 \mathrm{~b}$ \\
\hline & $\mathrm{T} 2$ & 72 & $17.6 \pm 8.2$ & $65 \pm 12$ & $129 \pm 8 \mathrm{ab}$ & $58.9 \pm 7.0 \mathrm{a}$ \\
\hline & T3 & 82 & $24.4 \pm 10.1$ & $76 \pm 11$ & $140 \pm 9 a$ & $59.7 \pm 6.9 a$ \\
\hline & $\mathrm{T} 4$ & 149 & $21.7 \pm 10.7$ & $76 \pm 8$ & $138 \pm 15 \mathrm{a}$ & $57.0 \pm 6.7 \mathrm{ab}$ \\
\hline \multirow[t]{4}{*}{2011} & T1 & 0 & $31.9 \pm 7.4$ & $74 \pm 13$ & $134 \pm 12 b$ & $56.9 \pm 3.7 b$ \\
\hline & $\mathrm{T} 2$ & 42 & $37.0 \pm 13.1$ & $79 \pm 10$ & $141 \pm 11 \mathrm{ab}$ & $62.1 \pm 7.9 \mathrm{a}$ \\
\hline & $\mathrm{T} 3$ & 69 & $37.2 \pm 8.5$ & $85 \pm 7$ & $149 \pm 14 \mathrm{a}$ & $64.0 \pm 6.6 \mathrm{a}$ \\
\hline & $\mathrm{T} 4$ & 135 & $38.0 \pm 11.1$ & $84 \pm 8$ & $147 \pm 11 \mathrm{a}$ & $62.7 \pm 6.8 \mathrm{a}$ \\
\hline
\end{tabular}

homogenisation. Extracts were allowed to stand at room temperature for $1 \mathrm{~h}$ to sediment, before an aliquot of the supernatant was directly used for the analysis of TPC by the FolinCiocalteu method [42] and the FRAP method [43]. Both tests were carried out on a Konelab Arena 20XT analyser (Thermo Fisher Scientific Oy, Vantaa, Finland). An external catechin standard calibration was used for quantification, and the results were expressed as $\mathrm{mg}$ catechin equivalents (CE) $100 \mathrm{~g}^{-1}$ edible fruit (FM) [42,43].

Vitamin $\mathrm{C}$, ascorbic acid and dehydroascorbic acid were quantified after extracting $5.0 \mathrm{~g}$ of the above-mentioned frozen powder with $50 \mathrm{~mL}$ phosphate buffer containing $1 \mathrm{~g} \mathrm{~L}^{-1} \mathrm{DL}$ dithiothreitol. After $2 \mathrm{~h}$ at room temperature in order to reduce the dehydroascorbic acid, the extracts were filtered through a 0.45 - $\mu \mathrm{m}$ filter, measured by HPLC-UV, and quantified with an external ascorbic acid standard calibration [44]. All extractions were done in duplicate and analysed twice.

\subsection{Measurements of soil water status}

To determine the soil water status, granular matrix probes (Watermark ${ }^{\circledR}$ probes, IRROMETER Company, Inc., Riverside, CA, USA) were installed at 0.30 and $0.60 \mathrm{~m}$ depths to get the $\Psi$ soil, approximately vertically under the dripper line. The median value of three repeated probe values at each depth in each subplot was considered in order to schedule optimal irrigation.

Capacitance measurements were obtained from access tubes (Aquapro Sensors, Reno, NV, USA) at six soil depths from 0.15 to $0.90 \mathrm{~m}$, at a distance from the tree row of $0.25 \mathrm{~m}$. The measurement scale is in \%Aquapro, and according the manufacturer's instructions the $100 \%$ value is considered as field capacity and values around $40 \%$ correspond to the lowest limit for water availability by the plant in a loam soil. Two Aquapro tubes were installed in each subplot. For both measurement systems, probes and tubes were located only in one replication.

\subsection{Measurements of plant water status}

$\Psi$ stem and predawn leaf water potential $(\Psi p d)$ were used for assessing plant water status. They were determined us- ing a Scholander pressure chamber (Model 600; PMS Instrument Company, Albany, OR, USA) [45]. Measurements were made on one leaf per reference tree, i.e., 12 measurements per irrigation treatment including both subplots. $\Psi$ stem monitoring was done every 3-4 days from early June to several days before harvest at solar noon, leaving the leaves covered in an aluminium foil before measurement. The duration for leaf sampling and measurements was 60 to $90 \mathrm{~min} . \Psi p d$ was measured 5 times during the growing season in total darkness, between 03:00 and 04:00 am (solar time).

\subsection{Data analysis}

All statistical analyses were carried out using XLSTAT 2010. To compare the influence of the different treatments, data were subjected to an analysis of variance (ANOVA), and the significant differences were analysed with Tukey's test at a level of $95 \%(P<0.05)$. The two tree shape systems were pooled, because no significant interactions were found between them and the irrigation treatments (data not shown). Relationships between factors were analysed by simple linear regression and by the coefficient of determination $\left(R^{2}\right)$.

\section{Results and discussion}

\subsection{Water application, fruit yield, fruit weight and stem development}

Irrigation water differed sharply according to the irrigation treatment. The 2010 and 2011 average amount for T4 was $142 \mathrm{~mm}$ during the season (table II). For T3 (RDI) and T2, it was limited to 75 and $57 \mathrm{~mm}$, which means water saving of $47 \%$ and $60 \%$, respectively. The treatments did not induce any significant difference in yields. The treatments without irrigation during all or part of the season $(\mathrm{T} 1, \mathrm{~T} 2)$ produced the smallest fruits and lowest Class A percentage. The trunk diameter measured at the end of 2010 and 2011 showed clearly less trunk growth on these water-stressed trees, especially for the treatment with no irrigation, compared with full-irrigated and RDI trees. These plants were less vigorous and in the long term might produce less fruits. 
Table III. Soluble solid and malic acid contents, firmness, total phenolic compounds (TPC), and vitamin C contents of the apple fruits in 2010 in relation to the different irrigation strategies: no irrigation (T1); optimal irrigation except no irrigation during July to the beginning of August (T2); optimal irrigation except regulated deficit irrigation (RDI) during July to the beginning of August (T3); optimal irrigation (T4). Each data value corresponds to the mean ( \pm standard deviation) of 2 training systems and 3 replications. Different letters indicate significant differences among the treatments (Tukey, $P<0.05$ ).

\begin{tabular}{|c|c|c|c|c|c|c|}
\hline Treatments & $\begin{array}{c}\text { Soluble solids } \\
\left({ }^{\circ} \text { Brix }\right)\end{array}$ & $\begin{array}{c}\text { Malic acid } \\
\mathrm{g} \mathrm{kg}^{-1}\end{array}$ & $\begin{array}{c}\text { Firmness } \\
\mathrm{kg} \mathrm{cm}^{-2}\end{array}$ & $\begin{array}{c}\text { TPC } \\
\mathrm{Me} \mathrm{CE}{ }^{\mathrm{a}} 100 \mathrm{~g}^{-1}\end{array}$ & 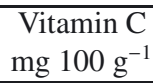 & $\begin{array}{c}\text { FRAP } \\
\mathrm{mg} \mathrm{CE}^{\mathrm{a}} 100 \mathrm{~g}^{-1}\end{array}$ \\
\hline T1 & $12.6 \pm 0.8$ & $4.7 \pm 0.4$ & $9.5 \pm 1.2$ & $99 \pm 15$ & $4.7 \pm 0.8$ & $115 \pm 10$ \\
\hline $\mathrm{T} 2$ & $12.4 \pm 0.9$ & $4.8 \pm 0.4$ & $9.6 \pm 0.9$ & $91 \pm 16$ & $4.8 \pm 0.5$ & $106 \pm 7$ \\
\hline $\mathrm{T} 3$ & $12.0 \pm 1.0$ & $4.5 \pm 0.2$ & $9.2 \pm 1.0$ & $92 \pm 16$ & $4.2 \pm 0.7$ & $104 \pm 9$ \\
\hline $\mathrm{T} 4$ & $12.1 \pm 0.8$ & $4.6 \pm 1.2$ & $9.1 \pm 0.7$ & $92 \pm 19$ & $4.2 \pm 0.4$ & $104 \pm 16$ \\
\hline
\end{tabular}

${ }^{\mathrm{a}} \mathrm{CE}=$ catechin equivalent.

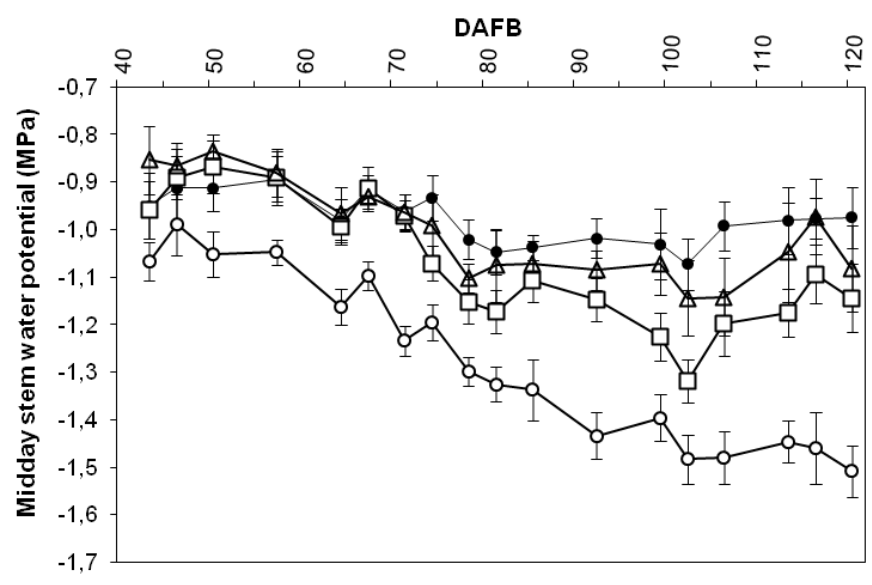

Figure 2. Midday stem water potential ( $\Psi$ stem) in 2010 in relation to the different irrigation strategies: T1, no irrigation (O); T2, optimal irrigation except no irrigation during July to the beginning of August (ם); T3, optimal irrigation except regulated deficit irrigation (RDI) during July to the beginning of August $(\triangle)$; T4, optimal irrigation (•). Each point corresponds to the mean of 12 measurements (vertical bars indicate standard deviations). Days after full bloom (DAFB): 6-36 corresponded to May, 37-66 to June, 67-97 to July and 98-128 to August.

No significant impact of RDI was found on any agronomic parameter (table II). This confirms results found in pear $[46,47]$, almond [48] and loquat [18]. However, some authors suggested that a moderate water deficit during the fruit growth stage decreased apple yield [9]. In this study, $\Psi$ stem lower than $-1.2 \mathrm{MPa}$ during summer had a negative impact on fruit size compared with optimal irrigation. These results on fruit size confirm similar effects obtained in semi-arid climates with apples [11]. A threshold of $\Psi$ stem at -1.2 MPa was suitable for RDI for both experimental years (figure 2).

\subsection{Fruit quality}

One of the goals in this study was to evaluate the possible influence of irrigation on commercial quality parameters and nutritional parameters. The results showed a slight tendency toward higher SSC, fruit firmness, vitamin C contents and TPC with increasing plant stress (table III). Smaller fruit size on stressed trees (T1 and T2) could explain this result through a

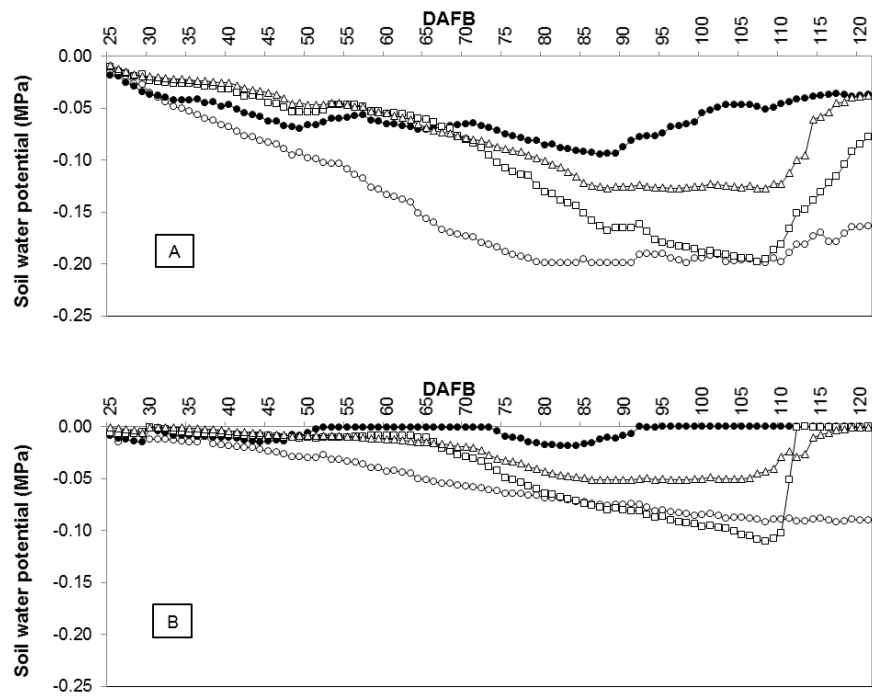

Figure 3. Soil water potential ( $\Psi$ soil $)$ at $0.3 \mathrm{~m}(\mathrm{~A})$ and $0.6 \mathrm{~m}(\mathrm{~B})$ soil depth in 2010 in relation to the different irrigation strategies: T1, no irrigation (O); T2, optimal irrigation except no irrigation during July to the beginning of August ( $\square)$; T3, optimal irrigation except regulated deficit irrigation (RDI) during July to the beginning of August $(\triangle)$; T4, optimal irrigation ( $)$. Each point corresponds to the mean of six measurements. Days after full bloom (DAFB): 6-36 corresponded to May, 37-66 to June, 67-97 to July and 98-128 to August.

concentration effect. Similar results confirm the effect of water stress on phytochemical compounds in apples $[49,50]$. However, this influence is very moderate compared with that of cultivars. In a study comparing 104 cultivars, the range of TPC was between 52 and $379 \mathrm{mg} \mathrm{CE} 100 \mathrm{~g}^{-1}$ and the range of antioxidant potential was between 42 and $429 \mathrm{mg}$ CE $100 \mathrm{~g}^{-1}$ of edible fresh matter [39], while the TPC increase as a consequence of the irrigation regime does not exceed $7 \%$ in this study.

\subsection{Soil water status}

During the experiment, $\Psi$ soil measured with Watermark ${ }^{\circledR}$ probes decreased to about $-0.20 \mathrm{MPa}$ at $0.30 \mathrm{~m}$ depth without irrigation in 2010 (figure 3), whereas at $0.60 \mathrm{~m}$ the decrease was less significant, about $-0.10 \mathrm{MPa}$. This difference was 

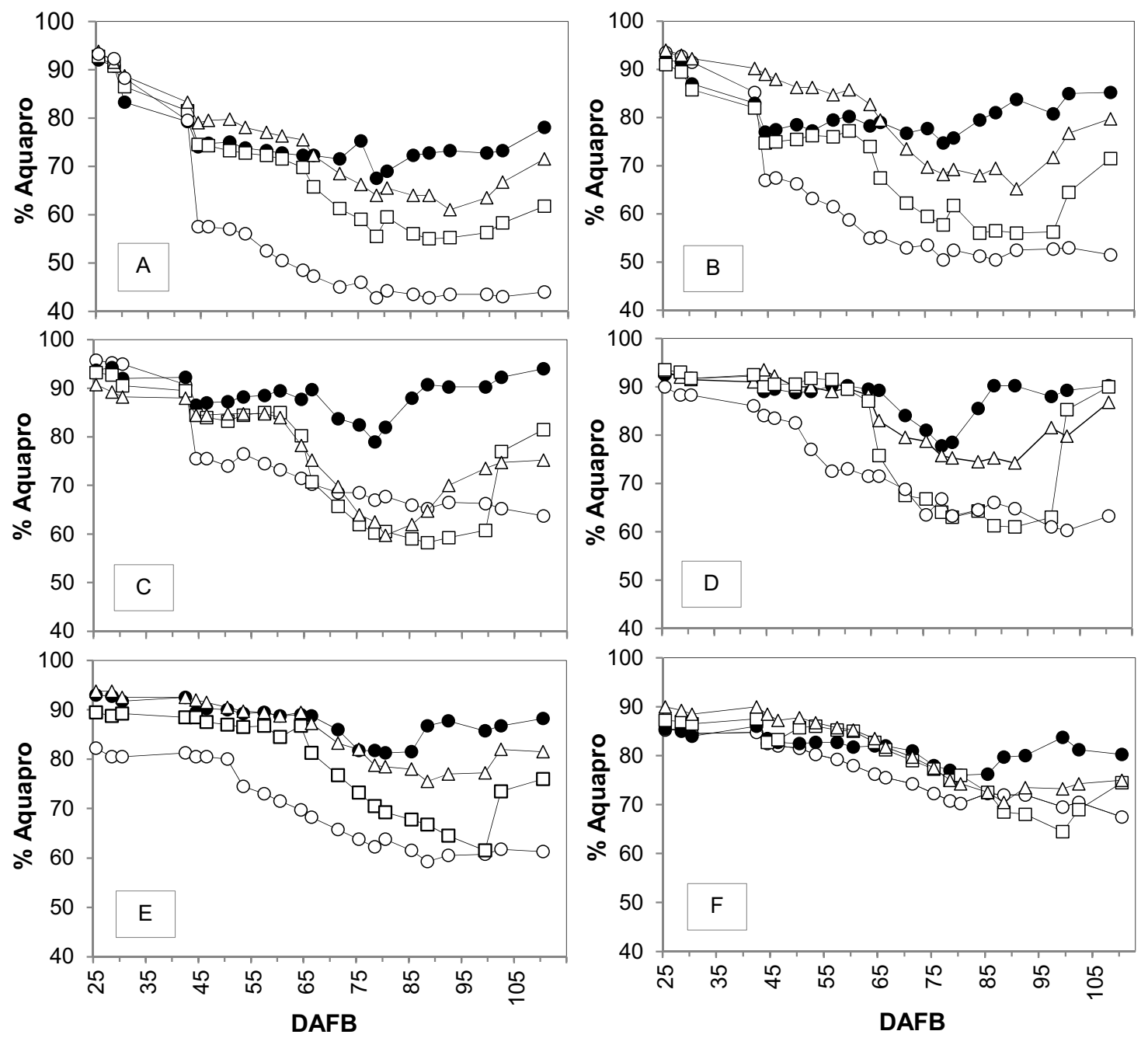

Figure 4. Capacitance measurements, expressed in \%Aquapro (with a $100 \%$ value considered as field capacity and values around $40 \%$ as the lowest limit for water availability by the plant in a loam soil) at different soil depths (A: 0.15, B: 0.30, C: 0.45 , D: 0.60 , E: 0.75 and F: 0.90 $\mathrm{m})$ in 2010 in relation to the different irrigation strategies: T1, no irrigation (O); T2, optimal irrigation except no irrigation during July to the beginning of August ( $\square$ ); T3, optimal irrigation except regulated deficit irrigation (RDI) during July to the beginning of August ( $\triangle$ ); T4, optimal irrigation (-). Each point is the mean of four measurements. Days after full bloom (DAFB): 6-36 corresponded to May, 37-66 to June, 67-97 to July and $98-128$ to August.

due to higher root density at $0.30 \mathrm{~m}$ than at $0.60 \mathrm{~m}$ (figure 1 ). In contrast, with optimal irrigation, $\Psi$ soil decreased only to $-0.08 \mathrm{MPa}$ at $0.30 \mathrm{~m}$ below ground level and $-0.02 \mathrm{MPa}$ at $0.60 \mathrm{~m}$. The treatments with no irrigation (T2) and RDI (T3) during July to the beginning of August showed an intermediate evolution. In T3, $\Psi$ soil reached -0.12 and $-0.05 \mathrm{MPa}$ at $0.30 \mathrm{~m}$ and $0.60 \mathrm{~m}$ soil depth, respectively. Restoring optimal irrigation in August for these two treatments induced a quick rise in $\Psi$ soil values, up to optimal water availability, as expected $[8,51]$.

Capacitance measurements in the Aquapro access tubes showed fewer differences among irrigation treatments with increasing soil depth (figure 4). At a given soil depth, a change in the curve slope may indicate a decrease in water availability. In general, a significant decrease in soil water content (SWC), indicating easy water uptake, was followed by a flattening of the curve, suggesting that water availability was becoming critical at this level. For the no-irrigation control treatment (T1), such a signal appeared successively with increasing soil depth. For the upper soil layers $(15-45 \mathrm{~cm})$ where the root density is highest, the flattening of the curve was detectable at 30 to 35 DAFB. Most of the tree water supply was then covered by available water at 0.60 and $0.75 \mathrm{~m}$ soil depth until critical depletion, occurring four weeks later (about 65 DAFB). The critical threshold of the non-limiting water range seemed to be different according to soil depth: $55 \%$ at $0.30 \mathrm{~m}$ and $65-75 \%$ at 0.45 to $0.75 \mathrm{~m}$. Values at $0.90 \mathrm{~m}$ are rather stable throughout the season, indicating that this soil layer has a lower direct contribution to tree water uptake due to weak root colonisation.

Capacitance measurements in the Aquapro access tubes showed a close evolution at 0.3 and $0.6 \mathrm{~m}$ (figure 4) compared with $\Psi$ soil, meaning that the relationship between SWC and $\Psi$ soil was strong at both soil depths (figure 5). This indicates 

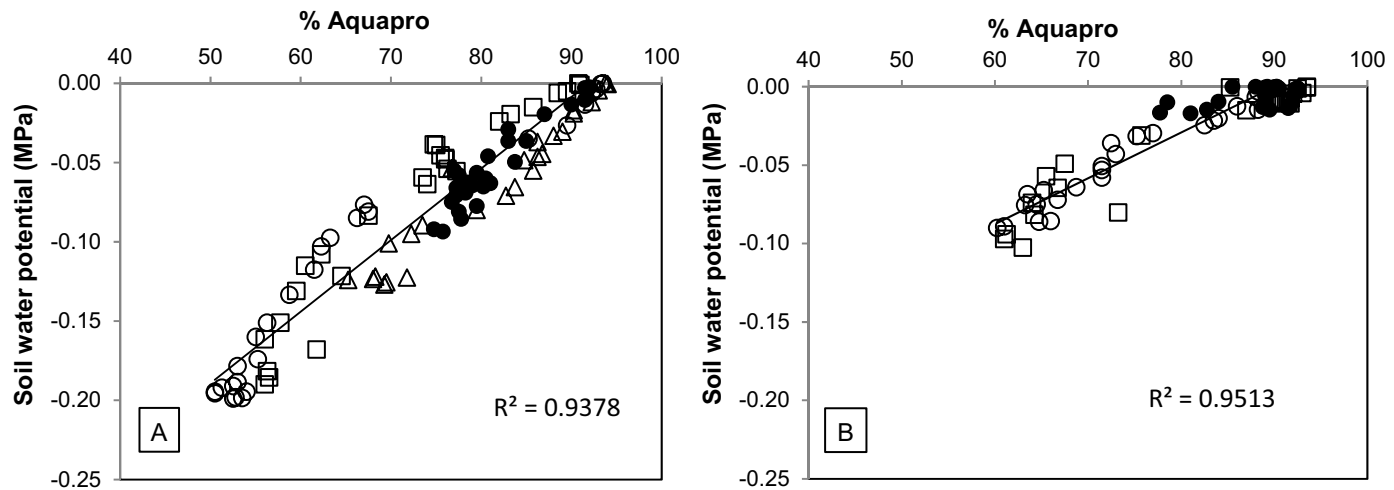

Figure 5. Relationships between soil water potential ( soil $_{\text {) }}$ and capacitance measurements, expressed in \%Aquapro (with a $100 \%$ value considered as field capacity and values around $40 \%$ as the lowest limit for water availability by the plant in a loam soil) at $0.3 \mathrm{~m}$ soil depth (A) and at $0.6 \mathrm{~m}(\mathrm{~B})$ in 2010 considering the different irrigation strategies: T1, no irrigation (O); T2, optimal irrigation except no irrigation during July to the beginning of August ( $\square$ ); T3, optimal irrigation except regulated deficit irrigation (RDI) during July to the beginning of August ( $\triangle$ ); T4, optimal irrigation $(\bullet)$.

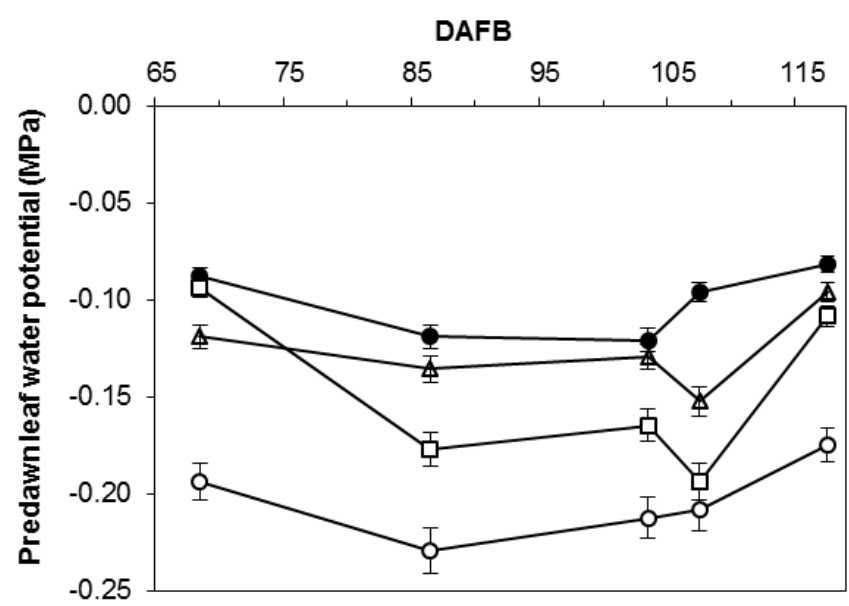

Figure 6. Predawn plant water potential $(\Psi p d)$ in 2010 for the different irrigation strategies: T1, no irrigation (O); T2, optimal irrigation except no irrigation during July to the beginning of August ( $\square$ ); T3; optimal irrigation except regulated deficit irrigation (RDI) during July to the beginning of August $(\triangle)$; T4; optimal irrigation $(\bullet)$. Each point corresponds to the mean of 12 measurements (vertical bars indicate standard deviations). Days after full bloom (DAFB): 6-36 corresponded to May, 37-66 to June, 67-97 to July and 98-128 to August.

that both measurement methods give reliable results in the range of 0.0 to $-0.2 \mathrm{MPa} \Psi$ soil. However, the slopes of the regression curve between the two depths were quite different, which confirms that limiting water availability may occur at different SWC according to soil depth. In fact, the correspondence between SWC and $\Psi$ soil depends on soil composition; even if the granulometry seems to be similar in all the layers observed, there are differences in organic matter between soil layers (table I) that can explain the differences between the two soil layers.

\subsection{Plant water status}

The data range of $\Psi p d$ in this study was between -0.08 and $-0.23 \mathrm{MPa}$ during summer (figure 6). Such small differences between irrigated and non-irrigated plants could be explained by the fact that the root systems of the trees were partially supplied by a restricted humid zone such as groundwater [52]. Plants submitted to drought of the whole root depth reached much lower values of $\Psi p d$. In T1 and T2, which received no irrigation during summer, available water was probably supplied by lower root layers, as indicated in figure $4 F$. However, the SWC remained very stable in these soil layers throughout the season, indicating that this water cannot be considered a water reserve for this treatment due to low root density (figure 1). The low water uptake might be sufficient for night plant rehydration, thereby avoiding a strong decrease in $\Psi p d$ during the season without irrigation. Nevertheless, a high coefficient of determination $\left(R^{2}\right)$ between $\Psi p d$ and $\Psi$ soil was observed in this study (figure 7) as well as in other studies; for example, a study on grapevine [53]. This can be explained by the large range of $\Psi$ soil, between -0.04 and $-0.20 \mathrm{MPa}$ during the season, with different values for stressed and non-stressed apple trees according to the irrigation management. However, studies on this topic suggested that predawn plant water potentials were not a consistent measurement for managing irrigation, especially under well-watered conditions [52,54]. Further to such limitation, for managing irrigation, $\Psi$ stem should be preferred in case of anisohydric behaviour [55]. Apple trees display in general anisohydric characteristics [56].

Istem very clearly separated the four irrigation treatments in this experiment (figure 2). The suitability of the $-1.2 \mathrm{MPa}$ $\Psi$ stem as an adequate threshold for deficit irrigation scheduling, despite experiments in very different climatic and soil conditions (i.e., Israel and Spain), confirms its wide suitability for cultivars with the specified behaviour $[28,29]$. However, the measurement of $\Psi$ stem is very time-consuming and until now there has been no system available to measure leaf water potential electronically. Since the relationship between $\Psi$ stem and $\Psi$ soil was well established, especially at the $0.3 \mathrm{~m}$ soil depth (table IV, figure 8), this study pointed out that with high-frequency subsurface irrigation at $0.25 \mathrm{~m}$ below ground level, the measurement of soil water status with Watermark ${ }^{\circledR}$ probes is accurate at a soil depth of $0.30 \mathrm{~m}$. For scheduling 

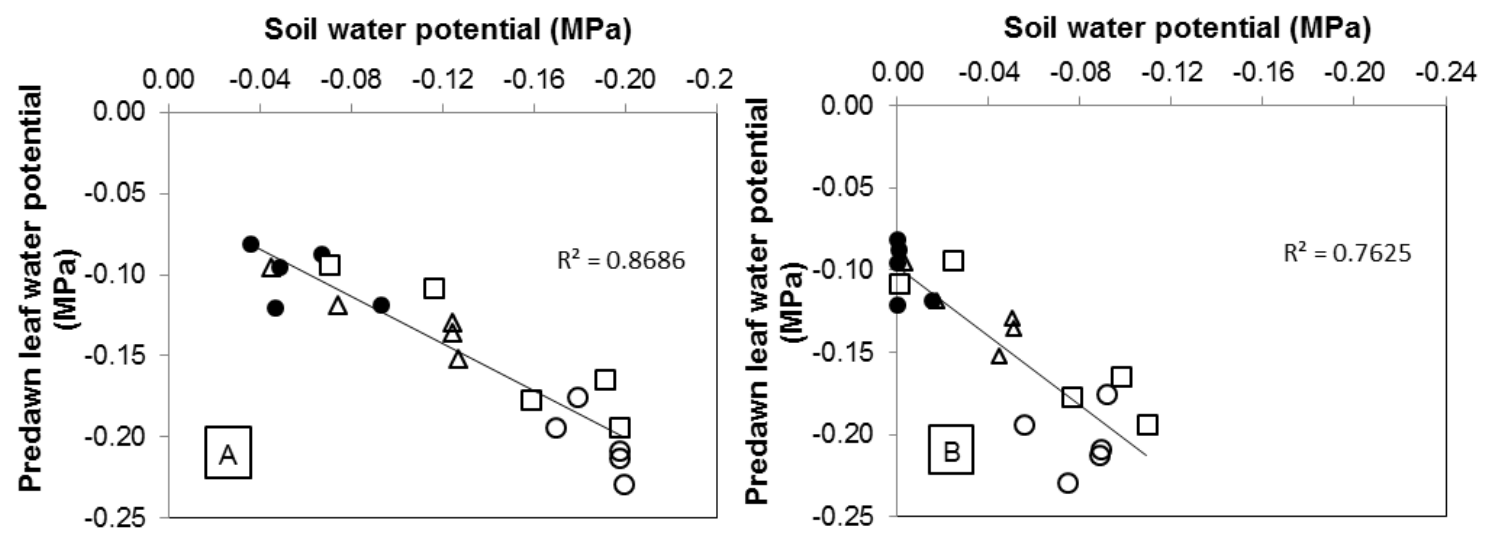

Figure 7. Relationships between predawn water potential $(\Psi p d)$ and soil water potential ( $\Psi$ soil $)$ at $0.3 \mathrm{~m}$ soil depth (A) and at $0.6 \mathrm{~m}(\mathrm{~B})$ in 2010 considering different irrigation strategies: T1, no irrigation (O); T2, optimal irrigation except no irrigation during July to the beginning of August $(\square)$; T3, optimal irrigation except regulated deficit irrigation (RDI) during July to the beginning of August ( $\Delta$ ); T4, optimal irrigation (•).
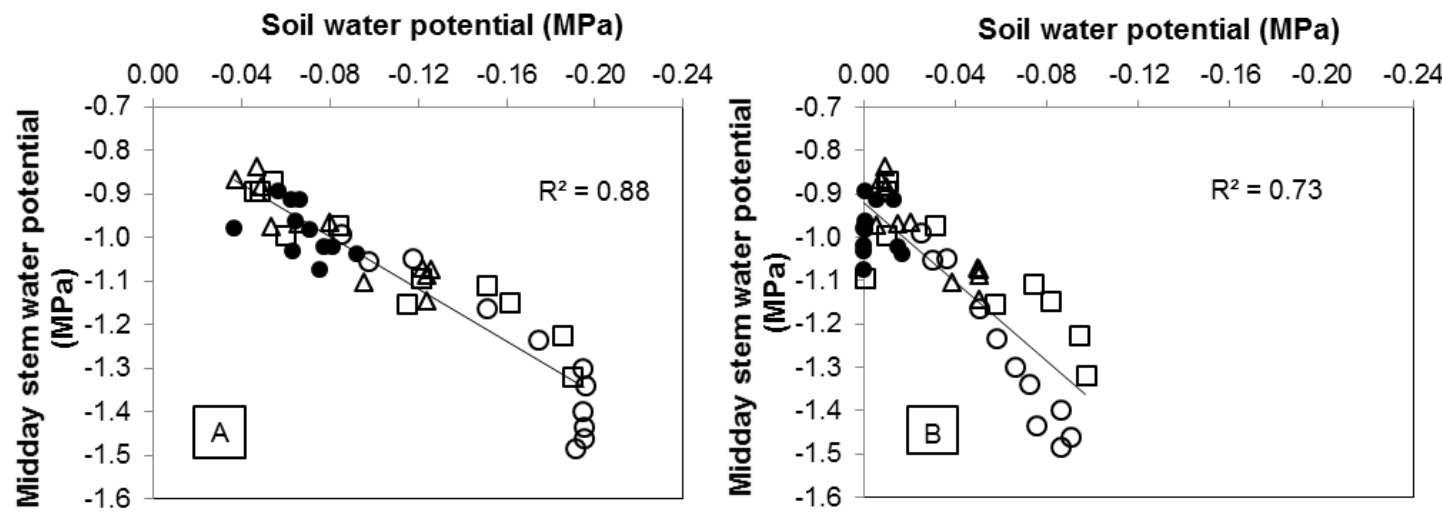

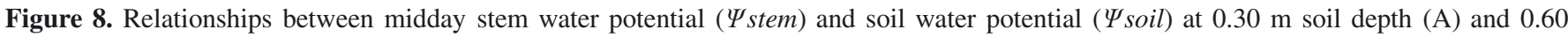
$\mathrm{m}$ (B) in 2010 considering different irrigation strategies: T1, no irrigation (O); T2, optimal irrigation except no irrigation during July to the beginning of August ( $\square$ ); T3, optimal irrigation except regulated deficit irrigation (RDI) during July to the beginning of August ( $\triangle$ ); T4, optimal irrigation $(\bullet)$.

Table IV. Relation between soil water potential ( $\Psi$ soil) and midday stem potential $(\Psi$ stem) for two soil depths, as well as capacitance measurements, expressed in \% Aquapro and midday stem potential ( $\Psi$ stem) at six different soil depths in 2010 . The values correspond to the coefficient of determination $\left(R^{2}\right)$ of the respective relationships.

\begin{tabular}{|c|c|c|c|c|c|c|c|c|c|c|}
\hline \multirow{2}{*}{$\begin{array}{l}\text { Soil depth } \\
\text { (m) }\end{array}$} & \multicolumn{3}{|c|}{$\Psi$ soil to $\Psi$ stem relationship } & \multicolumn{7}{|c|}{ Capacitance measurements to $\Psi$ stem relationship } \\
\hline & 0.3 & 0.6 & Mean & 0.15 & 0.30 & 0.45 & 0.60 & 0.75 & 0.90 & Mean \\
\hline$R^{2}$ & 0.88 & 0.73 & 0.85 & 0.82 & 0.73 & 0.47 & 0.69 & 0.86 & 0.64 & 0.81 \\
\hline
\end{tabular}

RDI in the experimental orchard with Watermark sensors, the calculated $\Psi$ soil threshold values of -0.15 and $-0.08 \mathrm{MPa}$, respectively, for $0.30 \mathrm{~m}$ and $0.60 \mathrm{~m}$ depth turned out to be adequate for RDI. Compared with on-surface drip irrigation, subsurface irrigation, especially with high-frequency water application, avoided risky situations such as when water supplies lower than $1 \mathrm{~mm} \mathrm{day}^{-1}$ (as in T4) would probably have wetted a very shallow soil layer, poorly colonised by roots and more exposed to a higher evaporation rate. With subsurface irrigation, water is injected into the most efficient root layer. This might also be a reason for the high coefficient of determination $\left(\mathrm{R}^{2}\right)$ between $\Psi$ soil and $\Psi$ stem, and why the $-1.2 \mathrm{MPa}$ $\Psi$ stem threshold could be detected in a $\Psi$ soil threshold, which was confirmed to be suitable for this particular orchard in subsequent seasons (data not shown).

\section{Conclusion}

For the apple orchard under study with high-frequency subsurface irrigation, the optimal irrigation did not significantly impact fruit yields for two consecutive years compared with absence of irrigation. However, fruit weight was significantly increased compared with the non-irrigated treatments inducing a $\Psi$ stem value considerably lower than $-1.2 \mathrm{MPa}$ during the summer period. In contrast, fruit quality responded 
slightly negatively to optimal watering, suggesting a dilution phenomenon. Moderate water stress, not lower than $-1.2 \mathrm{MPa}$ $\Psi$ stem, did not influence fruit size, commercial quality or nutritional quality (SSC, total phenolic compounds and vitamin C) compared with optimal irrigation. However, this moderate stress saved approximately $50 \%$ of water compared with the optimal irrigation.

Isoil proved to be an adequate and easily measurable indicator for RDI scheduling. In this experiment there was a strong relationship between $\Psi$ soil and $\Psi_{\text {stem }}\left(R^{2}=0.91\right)$. The calculated $\Psi$ soil threshold values of -0.15 and $-0.08 \mathrm{MPa}$ for $0.30 \mathrm{~m}$ and $0.60 \mathrm{~m}$ soil depth, respectively, turned out to be suitable for scheduling RDI.

These results contribute to improving the use of tools measuring $\Psi$ soil and $\Psi$ stem for irrigation scheduling of apple orchards, allowing deficit irrigation, and saving water without reducing yield and fruit quality.

Acknowledgements. The authors thank Agroscope, Switzerland, and the Ministry of Superior Education and Scientific Research of Algeria for the financing of the doctoral thesis of the first author. Technical assistance during sample preparation, and polyphenol and FRAP determinations by Maria Ceymann, and vitamin $\mathrm{C}$ quantification by Martin Heiri are gratefully acknowledged.

\section{References}

[1] Ashraf M., Inducing drought tolerance in plants: recent advances, Biotechnol. Adv. 28 (2010) 169-183.

[2] Thompson T.L., Pang H.C., Li Y.Y., The potential contribution of subsurface drip irrigation to water-saving agriculture in the Western USA, Agr. Sci. China 8 (2009) 850-854.

[3] Hoffman G.J., Martin D.L., Engineering systems to enhance irrigation performance, Irrig. Sci. 14 (1993) 53-63.

[4] Heard, J.W., Porker, M.J., Armstrong D.P., Finger L., Ho C.K.M., Wales W.J., Malcolm B., The economics of subsurface drip irrigation on perennial pastures and fodder production in Australia, Agric. Water Manage. 111 (2012) 68-78.

[5] Ayars J.E., Phene C.J., Hutmacher R.B., Davis K.R., Schoneman R.A., Vail S.S., Mead R.M., Subsurface drip irrigation of row crops: a review of 15 years of research at the Water Management Research Laboratory, Agric. Water Manage. 42 (1999) 1-27.

[6] Torrecillas A., Domingo R., Galero R., Ruiz-Sánchez M.C., Apricot tree response to withholding irrigation at different phenological periods, Sci. Hortic. 85 (2000) 201-215.

[7] Girona J., Gelly M., Mata M., Arbones A., Rufat J., Marsal J., Peach tree response to single and combined deficit irrigation regimes in deep soils, Agric. Water Manage. 72 (2005) 97-108.

[8] Pérez-Pastor A., Domingo R., Torrecillas A., Ruiz-Sánchez M.C., Response of apricot trees to deficit irrigation strategies, Irrig. Sci. 27 (2009) 231-242.

[9] Leib B.G., Caspari H.W., Redulla C.A., Andrews P.K., Jabro, J.J., Partial rootzone drying and deficit irrigation of 'Fuji' apples in a semi-arid climate, Irrig. Sci. 24 (2006) 85-99.

[10] O'Connell M.G., Goodwin I., Response of "Pink Lady" apple to deficit irrigation and partial rootzone drying: physiology, growth, yield and fruit quality, Aust. J. Agric. Res. 58 (2007) 1068-1076.
[11] Naor A., Naschitz S., Peres M., Gal Y., Responses of apple fruit size to tree water status and crop load, Tree Physiol. 28 (2008) 1255-1261.

[12] Mpelasoka B.S., Behboudian M.H., Mills T.M., Effects of deficit irrigation on fruit maturity and quality of "Braeburn" apple, Sci. Hortic. 90 (2001) 279-290.

[13] Ebel R.C., Proebsting E.L., Evans R.G., Deficit Irrigation to control vegetative growth in apple and monitoring fruit growth to schedule irrigation, HortScience 30 (1995) 1229-1232.

[14] Chalmers D.J., Mitchell P.D., van Heek L., Control of peach tree growth and productivity by regulated water supply, tree density and summer pruning, J. Am. Soc. Hortic. Sci. 106 (1981) 307-312.

[15] Mitchell P.D., Chalmers D.J., The effect of reduced water supply on peach tree growth and yields, J. Am. Soc. Hortic. Sci. 107 (1982) 853-856.

[16] González-Altozano P., Castel J.L., Regulated deficit irrigation in 'Clementina de Nules' citrus trees. I. Yield and fruit quality effects, J. Am. Soc. Hortic. Sci. Biotechnol. 74 (1999) 706-713.

[17] Romero P., Navarro J.M., García F., Ordaz P., Effects of regulated deficit irrigation during the pre-harvest period on gas exchange, leaf development and crop yield of mature almond trees, Tree Physiol. 24 (2004) 303-312.

[18] Cuevas J., Canete M.L., Pinillos V., Zapata A.J., Fernandez M.D., Gonzalez M., Hueso J.J., Optimal dates for regulated deficit irrigation in 'Algerie' loquat (Eriobotrya japonica Lindl) cultivated in southeast Spain, Agric. Water Manage. 89 (2007) $131-136$.

[19] Crisosto C.H, Johnson R.S., Luza J.G., Crisosto S.M. (1994). Irrigation regimes affect fruit soluble solids concentration and rate of water loss of 'O'Henry' peaches, HortScience 29 (1994) 1169-1171.

[20] Mills T.M., Behboudian M.H., Clothier B.E., Water relations, growth, and the composition of 'Braeburn' apple fruit under deficit irrigation, J. Am. Soc. Hortic. Sci. 121 (1996) 286-291.

[21] Boyer J., Liu R.H., Apple phytochemicals and their health benefits, Nutr. J. 3 (2004).

[22] Gerhäuser C., Cancer chemopreventive potential of apples, apple juice, and apple components (review), Planta Med. 74 (2008) 1608-1624.

[23] Li S.H., Huguet J.G., Bussi C., Irrigation scheduling in a mature peach orchard using tensiometers and dendrometers, Irrig. Drainage Syst. 3 (1989) 1-12.

[24] Intrigliolo D.S., Castel J.R., Performance of various water stress indicators for prediction of fruit size response to deficit irrigation in plum, Agric. Water Manage. 83 (2006) 173-180.

[25] Abrisqueta I., Vera J., Tapiab L.M., Abrisqueta J.M., RuizSáncheza M.C., Soil water content criteria for peach trees water stress detection during the postharvest period, Agric. Water Manage. 104 (2012) 62-67.

[26] Campbell G.S., Campbell M.D., Irrigation scheduling using soil moisture mea-surements: theory and practice, Irrig. Sci. 1 (1982) 25-42.

[27] Silva C.R., Folegatti M.V., Silva T.J.A., Alves Junior J., Souza F.C., Ribeiro R.V., Water relations and photosynthesis as criteria for adequate irrigation management in 'Tahiti' lime trees, Sci. Agric. 62 (2005) 415-422.

[28] Naor A., Irrigation scheduling an evaluation of tree water status in deciduous orchards, Hortic. Rev. 32 (2006) 111-165.

[29] Girona J., Behboudian M.H., Mata M., Del Campo J., Marsal J., Exploring six reduced irrigation options under water shortage for 'Golden Smoothee' apple: Responses of yield components over three years, Agric. Water Manage. 98 (2010) 370-375. 
[30] Naor A., Midday stem water potential as a plant water stress indicator for irrigation scheduling in fruit trees, Acta Hortic. 537(2000) 447-454.

[31] McCutchan H., Shackel K.A., Stem-water potential as a sensitive indicator of water stress in prune trees (Prunus domestica L. cv French), J. Am. Soc. Hortic. Sci. 117 (1992) 607-611.

[32] Lampinen B.D., Shackel K.A., Southwick S.M, Olson W.H., Deficit irrigation strategies using midday stem water potential in prune, Irrig. Sci. 20 (2001) 47-54.

[33] De Swaef T., Steppe K., Raoul L., Determining reference values for stem water potential and maximum daily trunk shrinkage in young apple trees based on plant responses to water deficit, Agric. Water Manage. 96 (2009) 541-550.

[34] Romero P., Botia P., Garcia F., Effects of regulated deficit irrigation under subsurface drip irrigation conditions on water relations of mature almond trees, Plant Soil 260 (2004) 155-168.

[35] García-Tejero I., Romero-Vincente R., Jiménez-Bocanegra J.A., Martínez-Garcia G., Durán-Zuazo V.H., Muriel-Fernandez J.L., Response of citrus trees to deficit irrigation during different phenological periods in relation to yield, fruit quality and water productivity, Agric. Water Manage. 97 (2010) 689-699.

[36] Girona J., Mata M., del Campo J., Arbonés A., Bartra E., Marsal J., The use of midday leaf water potential for scheduling deficit irrigation in vineyards, Irrig. Sci. 24 (2006) 115-127.

[37] Jones H.G., Irrigation scheduling - comparison of soil, plant and atmosphere monitoring approaches, Acta Hortic. 792 (2008) 391-403.

[38] Bertschinger L., Neue Grundlagen für die Düngung der Obstkulturen, Schweizerische Zeitschrift für Obst- und Weinbau 3 (2003) 4-7.

[39] Goodwin I. and Boland A.-M. 2002 Scheduling deficit irrigation of fruit trees for optimizing water use efficiency, in: Food and Agricultural Organization (ed.), Deficit irrigation practices, Water Reports (FAO) 22, Rome (2002) 67-78.

[40] Naor A., Naschitz S., Peres M., Gal Y., Responses of apple fruit size to tree water status and crop load, Tree Physiol. 28 (2008), $1255-1261$.

[41] Rossier J., Pfammatter W., Aerny J., 1998: Assessment of internal apple quality by the Pimprenelle laboratory, Revue Suisse de Viticulture, d'Arboriculture et d' Horticulture 30 (1998), 247-252.

[42] Ceymann M., Arrigoni E., Schärer H., Baumgartner D., Bozzi Nising A., Hurrell R.F., Rapid high performance screening method using UHPLC-MS to quantify 12 polyphenol compounds in fresh apples, Anal. Methods 3 (2011), 1774-1778.
[43] Ceymann M., Arrigoni E., Schärer H., Bozzi Nising A., Hurrell R.F., Identification of apples rich in health-promoting flavan3 -ols and phenolic acids by measuring the polyphenol profile, J. Food Composit. Anal. 26 (2012) 128-135.

[44] Crespo P., Giné Bordonaba J.G., Terry L.A., Carlen C., (2010). Characterisation of major taste and health-related compounds of four strawberry genotypes grown at different Swiss production sites, Food Chem. 122 (2010) 16-24.

[45] Scholander P.F., Bradstreet E.D., Hemmingsen E.A., Hammel H.T., Sap pressure in vascular plants, Science 148 (1965) 339-346.

[46] Cheng F., Sun H., Shi H., Zhao Z., Wang Q., Zhang J., Effects of regulated deficit irrigation on the vegetative and generative properties of the pear cultivar 'Yali', J. Agric. Sci. Technol. 14 (2012) 183-194.

[47] Marsal J., Rapoport H.F., Manrique T., Girona J., Pear fruit growth under regulated deficit irrigation in container-grown trees, Sci. Hortic. 85 (2000) 243-259.

[48] Stewart W.L., Fulton A.E., Krueger W.H., Lampinen, B.D., Shackel K.A., Regulated deficit irrigation reduces water use of almonds without affecting yield, Calif. Agric 65 (2011) 90-95.

[49] Ebel R.C., Proebsting E.L., Patterson M.E., Regulated deficit irrigation may alter apple maturity, quality, and storage life, HortScience 28 (1993) 141-143.

[50] Stefanelli D., Brady S., Cornwall D., Goodwin I., Jones R., Effect of irrigation on yield, fruit sweetness and maturity of Royal Gala apples, Tree Fruit 5 (2012) 8-14.

[51] Ruiz-Sánchez M.C., Domingo R., Savé R., Biel C., Torrecillas A., Effects of water stress and rewatering on leaf water relations of lemon plants, Biol. Plant. 39 (1997) 623-631.

[52] Ameglio T., Archer P., Cohen M., Valancogne C., Daudet F.A., Dayau S., Cruiziat P., Significance and limits in the use of predawn leaf water potential for tree irrigation, Plant Soil 207 (1999) 155-167.

[53] Williams L.E., Araujo F.J., Correlation among predawn leaf, midday leaf, and midday stem water potential and their correlations with other measures of soil and plant water status in Vitis vinifera, J. Am. Soc. Hortic. Sci. 127 (2002) 448-454.

[54] Donovan L.A., Linton M.J., Richards J.H., Predawn plant water potential does not necessarily equilibrate with soil water potential under well-watered conditions, Oecologia 129 (2001) 328-335.

[55] Jones H.G., Monitoring plant and soil water status: established and novel methods revisited and their relevance to studies of drought tolerance, J. Exp. Bot. 58 (2007) 119-130.

[56] Jones H.G., Tardieu F., Modelling water relations of horticultural crops: a review, Sci. Hortic. 74 (1998) 21-46. 